\title{
Deixis of Narration: Research at the Student Education Indonesian Language and Literature, Faculty of Language and Literature, State University of Makassar
}

\section{Azis and Juanda}

Education Indonesian Language and Literature, Faculty of Language and Literature, State University of Makassar, Makassar, South Sulawesi, Indonesia

\section{Abstract}

This study aims to analyze deixis in the narration of student education Indonesian language and literature. The data sources were collected from the narrations of students in the 2014 academic year. The data were analyzed by using the content analysis method with reference to the various types of deixis. The research results

Corresponding Author:

Azis

azis@unm.ac.id

aznunu@gmail.com

Received: 6 April 2018

Accepted: 3 May 2018

Published: 26 July 2018

Publishing services provided by Knowledge $\mathrm{E}$

(c) Azis and Juanda. This article is distributed under the terms of

the Creative Commons

Attribution License, which

permits unrestricted use and

redistribution provided that the

original author and source are credited.

Selection and Peer-review under the responsibility of the ISLLE 2017 Conference Committee.

\section{G OPEN ACCESS}

show that the location of person deixis in a recurring sentence network is sometimes with a similar word. Second, the placement of spatial deixis is at the beginning of a sentence, the middle of a sentence, and the end of a sentence. Third, the placement of temporal deixis can be in the form of a deixis expressing start with the word of "sejak" (since) its location reside in the middle of a sentence. Temporal deixis there is also in the form of boundary time at the same time with the word 'sedari' (since) which its location be at middle sentence, while temporal deixis with the word 'sementara, ketika, dan selama' (whereas, when, and during) are located at the early sentence.

Keywords: deixis, narration, placement

\section{Introduction}

Each article, of course, has many differences between the posts with other writings that although the topic of writing has in common. It is this difference that indicates that the person writing may not have the same work, especially in narrative writing. Narrative as one piece in a discourse has the distinction of discourse argumentation, persuasion, description, and exposition, which is currently a tendency someone called "text" in Indonesian. Narrative writing style with deixis placement would be writing narrative force generated by its author. Problems in narrative deixis are fundamental 
and important in order to know how deixis is used. Deixis is not a new problem in language, but rather something that has been written by various language experts by showing various examples, albeit briefly, and not in the form of a narrative discourse.

By Observing, deixis as something that absolutely must be understood in the study of language is especially Indonesian language. The existence of a variety of things among the students in a narrative writing course in which various deixis used with a different placement of the article written a narrative with other narratives. Especially if you have written narrative titles are also different. Therefore, an understanding of the narrative deixis is something that really needs to be achieved so that the analysis of the results regarding student placement in the narrative deixis at the Education Indonesian Language and Literature Faculty of Language and Literature, State University of Makassar can be explored regarding the placement of deixis. The problem in this research is how the narrative deixis on student assignment Education Indonesian Language and Literature, Faculty of Language and Literature, State University of Makassar This study aimed to analyze the narrative deixis in Education student assignment Indonesian Language and Literature, Faculty of Languages and Literature, State University of Makassar. The theory used in connection with narration and deixis. Narrative or it could be called a narrative; some use the term "essay narration" and the term "narrative discourse" is also used.

Technical term for one of the most basic things we do with utterances. A deixis is clearly a form of referring that is tied to the speaker's context. Therefore, the language and the context becomes a matter that must be considered [1]. Dexis as things or functions that point to something beyond language; said point pronouns [2]. Number of significant differences between most written and spoken discourse [3]. This applies, particularly to deictic expressions. "Deixis" is not a pronoun, but also adverbs [4]. Furthermore, at the level of semantics, deixis demonstrative in many different languages. Deixis is a linguistic phenomenon about a person, object, or place in the situation [5]. Deixis refers to lexical and gestural items that depend on context for meaning [6].

Deixis is the encoding of the spatiotemporal context and subjective experience of the encoder in an utterance [7]. Deixis is the study of deictic in language, such as you, now, and today [8]. Deixis is pervasive in languages 'when', 'where', 'who', 'what' and so on, and it is very useful [9].

There are three types of deixis: person deixis, spatial deixis, and temporal deixis [1]. Deictic expressions include personal deixis, such as "you" and "I," temporal deixis, such as "today" and "next week," and spatial deixis, such as "here" and "there" [10]. Person deixis basically refers to pronouns [1]. Person deixis is an important component 
of pragmatics. In regard to the addresser, the addressee, and the third party involved in a conversation, person deixis indicates the social status, interpersonal relationship, and other factors of the conversational parties [11]. Furthermore, in considering spatial deixis, states that it is important to remember that a location, from the speaker's perspective, can be fixed mentally as well as physically. Psychological basis of temporal deixis seems to be similar to that of spatial deixis [1]. Furthermore, it is said that the time of disclosure in each language is different. Relevant research includes that conducted by [11] entitled "A Social and Pragmatic Analysis of the Second Person Deixis You." The results are applicable to an adequate translation of you.

\section{Methods}

The focus of the research is the narrative deixis about the task of a student at the Education Indonesian Language and Literature, Faculty of Languages and Literature, State University of Makassar and qualitative descriptive study. This research is a qualitative descriptive study with a view to collecting data, processing the data, analyzing the data, and presenting the data objectively about deixis in the narrative contained in the student assignment Indonesian Language and Literature Education Force 2014. Data in this research that placement person deixis, spatial deixis, and temporal deixis. The source of data in this research is the narrative assignment student Indonesian Language and Literature Education 2014. The techniques used for data collection is documentation. The data are analyzed by content analysis method with reference to the various types of deixis including placement person deixis, spatial deixis, and temporal deixis. The main theory used is based upon [1] theory concerning deixis.

\section{Results}

Deixis in the narrative suggests that the use of deixis in every article is fundamental to the continuation of the posts. Deixis is most often used in the narration that person deixis. Additionally, temporal deixis and spatial deixis also have a role in positioning. Therefore, the existence of deixis in the writings of an author necessarily appropriate reasoning power. Sometimes the placement of deixis is at the beginning of the sentence, sometimes in the middle of the sentence, and sometimes at the end of the sentence (Table 1). 
TABLE 1: Deixis of Narration.

\begin{tabular}{|c|c|c|c|}
\hline Placement/location & Beginning sentence & Middle sentence & Binal sentence \\
\hline person deixis & $\begin{array}{l}\text { I or Me (saya, aku, ku, -ku) } \\
\text { we (kita) } \\
\text { they (mereka) } \\
\text { he/she (beliau) }\end{array}$ & $\begin{array}{l}\text { You (anda) } \\
\text { he/she (beliau) }\end{array}$ & we (kamu) \\
\hline spatial deixis & & $\begin{array}{l}\text { here (di sini) } \\
\text { where (ke mano) }\end{array}$ & there (di sano) \\
\hline temporal deixis & $\begin{array}{l}\text { whereas, when, and during } \\
\text { (sementara, ketika, and } \\
\text { selama) }\end{array}$ & $\begin{array}{l}\text { since (sedari) } \\
\text { since (sejak) } \\
\text { before (sebelum) } \\
\text { and after (setelah) }\end{array}$ & \\
\hline
\end{tabular}

\subsection{Placement of person deixis}

For the first person singular deixis form "I" or "me" (saya, aku, ku-, -ku). The use of first deixis person shows the tendency of students in writing to use saya and $a k u$. Certainly there are fundamental differences between the deixis saya and aku, as saya is used in formal situations in contrast to $a k u$, which is considered a familiar form used in a relaxed situation. To use $k u$ - who was in front of the word, while - $k u$ was in the back with the words written in series. In addition, there is also the use of the deixis "we" (kami) exclusively in the first person plural; inclusive first person plural 'we' (kita) are sometimes used interchangeably.

Using the second person deixis "you" (anda) at the beginning, in the middle, and at the end of a sentence indicates the use of deixis in relation to the person who invited communications. It's just that this use is often considered less acceptable in communication. In addition, the deixis "they" (mereka) and "he/she" (beliau) also has a role in sustaining communications.

\subsection{Placement of spatial deixis}

To use spatial deixis was found, that 'here' (di sini), 'there' (di sana), and 'where' (ke mana). The deixis di sini in general is found at the beginning of the sentence and in the middle of the sentence. The deixis di sana is found in the middle of a sentence, and ke mano is found at the beginning and at the end of a sentence. 


\subsection{Placement of temporal deixis}

Temporal deixis as one part of the deixis it turns out, there is a temporal deixis limit beginning, the same temporal limit, and temporal deixis limit of a sequence. Temporal deixis showed a different placement though temporal deixis in one section, for example temporal deixis limit beginning. Neither happened on temporal deixis limit concurrent and sequential limits.

\section{Conclusion}

Deixis in good student narrative person deixis, spatial deixis, nor the temporal deixis can be concluded. Firstly, the placement of person deixis turns out there in the form of first, second, and third. (a) The first person deixis "I" (aku) and "me" (-ku) is found at the beginning and at the end of the sentence. (b) The second person deixis form the placement 'we' (kamu) were at the beginning and in the middle of a sentence; the deixis "you" (anda) and ( $k a u$ ) is found in the middle of a sentence. In addition, the placement of person deixis in a series of sentences is sometimes repeated with similar words. (c) The third person deixis "he/she" (ia) promulgated in the middle of the sentence, while "he/she" (dia), "they" (mereka), and "he/she" (beliau) are found at the beginning, in the middle, and at the end of the sentence.

Secondly, the spatial deixis words "here" (di sini) and "where" (ke mana) are placed in the middle of a sentence, in contrast to the use of "there" (di sana) at the beginning of sentences and also at the end of a sentence. Thirdly, the placement of temporal deixis can be deixis which stated deadline of the beginning of the word from the placement is in the middle of a sentence, while the word "since" (sejak) is placed at the beginning of sentences and also sometimes at the end of a sentence. Temporal deixis also represents a form of time limit in conjunction with the word "since" (sedari), which is placed in the middle of a sentence, while the temporal deixis words "whereas," "when," and "during' (sementara, ketika, and selama) are placed at the beginning of the sentence. In addition, the time deixis sequential time words "before" (sebelum) and "after" (setelah) are placed in the middle of a sentence.

\section{References}

[1] Yule G: Pragmatics.Oxford: Oxford University Press; 1996.

[2] Kridalaksana H: Kamus Linguistik. Jakarta: Gramedia; 2001. 
[3] Black E: Pragmatic Stylistics. Edinburgh: Edinburgh University Press Ltd; 2006.

[4] Amfo NAA: Akan Demonstratives. Selected Proceedings of the 37th Annual Conference on African Linguistics. 2007; 134-148.

[5] Mitkon, Ruslan. Anaphora Resolution. London: Pearson Education; 2002.

[6] Luchjenbroers J: Discourse, Gesture, and Mental Spaces Maneuvers: Inside versus outside F-space. Amsterdam: John Benjamins Publishing Company; 2006.

[7] Brown K: Encyclopedia of Language and Linguistics. Oxford: Elsevier; 2009.

[8] Levinson SC: Deixis. In The Handbook of Pragmatics. Australia: Blackwell Publishing Ltd; 2006.

[9] Griffiths P: An Introduction to English Semantics and Pragmatics. Edinburgh: Edinburgh University Press; 2006.

[10] Cummings L: Clinical Pragmatics. Cambridge: Cambridge University Press; 2009.

[11] Li Y: A Social and Pragmatic Analysis of the Second Person Deixis You. AAS. 2009; 5(12): 130-133. 